\title{
Strategies for community participation in developing countries
}

\author{
BR Chitambo, MA Cur student, Department of Advanced Nursing Sciences, Unisa \\ JE Smith, Lecturer, Department of Advanced Nursing Sciences, Unisa \\ VJ Ehlers, Senior Lecturer, Department of Advanced Nursing Sciences, Unisa
}

\begin{abstract}
Community participation has been hailed as the panacea for most community programmes. Community participation at high levels empowers communities, increases selfreliance, self-awareness and confidence in self-examination of problems and seeking solutions for them. Behavioural changes are promoted and utilisation and support of services is facilitated, which are of great importance to all community health efforts, especially in areas where the incidence of HIV/AIDS is high or increasing. The purpose of this article is to explore community participation strategies adopted in different countries for providing community health care services. Recommendations are provided for enhancing community participation in developing countries.
\end{abstract}

\section{Opsomming}

Gemeenskapsdeelname word beskou as die oplossing vir die meeste gemeenskapsprogramme. Gemeenskapsdeelname op hoë vlakke bemagtig gemeenskappe, verhoog selfonderhoud, selfbewustheid, and vertroue in die selfondersoek na probleme asook in die soeke na oplossings vir sodanige probleme. Gedragsveranderinge en die ondersteuning asook die benutting van dienste word aangemoedig, wat van deurslaggewende belang is vir alle gemeenskapsgesondheidspogings, veral in areas waar die voorkoms van MIV/VIGS hoog is, of waar dit toeneem. Die doel van die artikel is om strategieë vir gemeenskapsdeelname te ondersoek, wat in verskillende lande anvaar is vir die voorsiening van gemeenskapsgesondheidsdienste. Aanbevelings word gedoen om gemeenskapsdeelname in ontwikkelende lande te bevorder.

\section{Introduction}

Community participation is defined as community involvement or partnership between individual groups, organisations and health professionals in health and health activities (WHO 1995:225). People are empowered to express their rights to be active in the development of appropriate health services (NPPHCN 1999).

Since the adoption of the concept of primary health care (PHC) by the World Health Organization (WHO) member countries in 1978 at Alma Ata, community participation has been hailed as the panacea for most community programmes (Rifkin 1990:7; WHO 1995:25). This view has led to a paradigm shift in the provision of health care in developing countries. There has been a recognition that communities differ geographically in life styles, beliefs and values and therefore their involvement in programmes would enrich the provision of those programmes. The WHO and the United Nations Children's Education Fund (UNICEF) emphasised that merely giving health information to a community is not as effective in promoting optimum health as fostering community participation in the provision of services (Rifkin 1990:2). Furthermore, there is a shift from viewing health narrowly in terms of diseases to a broader perspective where health is an integral part of the socio-economic development, hence the promotion of multidisciplinary and multisectoral approaches to health (Rifkin 1990:2). The vital importance of a multidisciplinary, intersectoral team approach in the promotion and facilitation of community participation cannot be overemphasised (King 1996:220). The emphasis is therefore on community participation that suits local conditions.

\section{Statement of the problem}

The research problem concerns sustained community participation in the implementation of health care programmes, especially in developing countries.

Despite the globally acclaimed potential benefits of community participation in health care programmes, the implementation of such programmes with sustained community participation, poses numerous problems to health care planners and providers, especially in developing countries. Thus the purpose of this article is to investigate models of community participation implemented in different countries in order to recommend ways of implementing sustained community participation in health care programmes in developing countries. In order to contextualise the different models of community participation, this discussion will be introduced by investigating the terms community as well as community participation. Under the latter term the characteristics and levels of community participation, as well as factors enhancing and impeding the implementation thereof, will be addressed. The investigation of models of community participation in different countries will be followed by addressing the evaluation of community participation. Finally recommendations will be made for implementing community participation in health care programmes in developing countries. 


\section{Community and community participation}

The main objectives of a health care delivery system are equity, efficiency and effectiveness. To achieve community participation in health care, community health professionals should therefore focus their attention on the community as a client, implying that they should have a clear understanding of the terms community and community participation.

\section{Community}

The concept community has several meanings. The report on community health nursing of the expert committee of the WHO (1974:7) define a community as ... a social group determined by geographical boundaries and/or common values and interests. Its members know and interact with one another. It functions within a particular social structure and exhibits and creates norms, values and social institutions.

There are three distinctive characteristics that are highlighted in this definition summarised by Stanhope and Lancaster (1992:254) as spatial or common locality (structural), interpersonal networks (personal) and social support (functional). Most health literature reflect these three characteristics of a community. For example, Rifkin, Muller and Bichmann (1988:933) presented a community structurally in terms of geographical boundaries, socially in terms of basic interests and functionally in terms of target or risk groups. All these three definitions are important for the health professionals. Dennill, King, Lock and Swanepoel (1995:57) note that the definitions of a community in terms of the above categories do not specify some of the complexities that are present in the communities. Some of these complexities include the sharing of various aspects of basic existence and the bonding which develop between members of the community. Different classes, different interests, political, cultural and religious differences as well as different economic resources are critical issues that may act as barriers to community participation. The analysis of the concept of community highlights some complex issues that should be anticipated when facilitating the process of community particıpation. The complexity of the concept is aggravated when the concept of community is combined with the concept of participation.

\section{Community participation}

Community participation, community involvement, community action for health and partnership in health are the descriptions given to the important mechanism of facilitating change or health development through interaction with the community. The WHO and UNICEF recognise community participation as a fundamental factor in primary health care (PHC) but the problem lies in the identification of sustainable forms of community participation in the face of the different definitions and perceptions of community participation. To some promoters of community participation, this term implies contributions in terms of money, labour and materials by the community in the provision of health care. To other promoters it means representation by some community members on organisational structures. To another group promoters it may mean empowerment of a community to make decisions about its own affairs (Shishana \& Versfeld 1993:7).

The third meaning brings to light the term empowerment. It is important to understand this term or concept (empowerment) in relation to community participation because health care providers might seem to talk without implementing the required actions. Empowering includes recognising the broad and widely diverse kinds of power that resides in different cultures, ethnic groups and geographic locations (Apps 1994:147). Empowerment means giving power to the communities by enhancing their capacities in order that they realise their freedom and assume greater responsibility for their own lives or health. Three characteristics of empowerment relate to empowerment as access and control over needed resources, decision-making and problem-solving abilities and the acquisition of instrumental behaviour needed to interact effectively with others to obtain resources on a sustainable basis (Stanhope \& Lancaster 1996:491).

If the goal of the empowering process is to create a partnership, these three characteristics should be present and it is recommended that the approach be positive and focused on competencies rather than on problems or deficits. The interventions should be consistent with community cultural norms and communities' perceptions of the problem. The professionals should support the community in primary decision-making and bolster the communities' self esteem by recognising and using the communities' strengths and support networks (Stanhope \& Lancaster 1996:492).

Dennill et al. (1995:57) identified three important characteristics for community participation namely, that participation must be active, observation of peoples' rights and responsibilities to exercise power over decisions that affect their lives (a community must be aware of its own and the other peoples' perceptions, rights and responsibilities) there must be mechanisms available to allow the implementation of decisions made by the community

Fulfilment of these characteristics in practice has been noted as a problem in several countries especially due to lack of training and education to give sufficient skills to the communities to be able to handle the relevant health issues (WHO 1995:226). The three characteristics form Rifkin's definition of ideal community participation maintain that community participation is: ... a social process whereby specific groups, with shared needs living in a defined geographic area, actively pursue identification of their needs, make decisions and establish mechanisms to meet these needs (Rifkin et al. 1988:933). A continuum of community participation is described by Askew, Carballo, Rifkin and Saunders (1989:6). At one end of the continuum, community participation is described as a means to improving the delivery of health services but with no community control over them. At the other far end community participation is accepted as a means by which communities are encouraged to play an influential role in the process of health development and in controlling the services. The two extremes of community participation are not regarded as desirable and should be 
avoided. A balance between the two extremes should be worked out and this means equal partnership, which Farley (1993:244) defines as a means whereby health professionals establish true partnerships with citizens so that power and decision-making are shared. Such a co-operative process will enable both the community's expertise about their needs and competencies, as well as the health care professionals' knowledge about health issues and accessing of available resources to be combined in identifying needs and means of meeting these needs on a sustainable basis. Brown (1994:343) conducted a quantitative study of general practitioners and nurses in the inner city of Sheffield, in the United Kingdom, about community participation. Brown (1994:343) came up with a definition of community participation from the perceptions of the health professionals which states: ... community participation concerns a social and political process founded in part upon individual rights to choice, information and consultation but including other tangible collective mechanisms and rights of involvement and voice along with organizational and community development strategies that enable the participation of all groups in society.

This definition, besides capturing the three characteristics of community participation, also brings up three levels of participation namely individual level, group level and community level participation. Three desirable components of community participation are self-care, demedicalisation and democratisation of health services (Dennill et al. 1995:58). These components reflect the levels of participation in Brown's definition. However, it is important to note that the mechanisms differ in developed countries from those in developing countries.

WHO member countries realise that the broad principles that apply to the basic concept of community development also apply to health development programmes, thus the forms of participation may differ but the principles of community development must at least be met. The principles of community development include mutual involvement of both parties, motivation and stimulation of community to co-operate, relevance of projects to community needs, respect for human dignity through involvement in making decisions on matters affecting their lives, education of people, support from central level, attention to economic and social development, and promotion of inter sectoral action (Dennill et al. 1995:64).

\section{Levels of community participation}

The definition by Brown regarding community participation suggests levels of community participation in terms of groups at individual level, group level, and community level participation. These levels are important as health professionals have focused mainly on the participation of individuals and viewed health and health interventions from a microscopic perspective (Brown 1994:343; Sawyer 1995: 18; WHO 1995:226). Although it is important to take note of the levels at which people are participating in terms of groups it is also important to note the levels in terms of involvement in different activities. Rifkin (1990:12) came up with five levels of participation following an analysis of 100 case studies on community participation in health programmes. Rifkin (1990:12) states that people can be involved at any of the five levels of participation as follows: receiving benefits, services and information from experts;

- $\quad$ participation in programme activities, for example distribution of contraceptives or contributing money to the health programmes;

- $\quad$ participation in implementing health programmes such as choosing clinic sites or organising child welfare and nutrition clinics;

- $\quad$ participating in monitoring and evaluation of programmes; and

- $\quad$ participating in decision-making and planning.

Therefore it becomes important to determine and evaluate the level at which the communities participate. All levels of participation should be considered to ensure equal participation of all the groups involved. The community should be involved in the decision-making process regarding health policies and lay people such as village health workers or village development workers may be incorporated to facilitate the demedicalisation process in order that equal partnership between the community and the health professionals could be achieved

\section{Factors enhancing community participation}

Equal partnership, social justice and self-reliance are the goals in community participation requiring that the following preconditions have been met for different forms of community participation to be sustainable (NPPHCN 1999). First and foremost there must be political commitment and involvement from the government. Secondly the reorientation of health professionals is crucial. Thirdly, the development of self-management capabilities of local communities and the socio-economic situation in the country must be conducive to development. Dennill et al. (1995:74) state that ... only when all the members of the multidisciplinary, intersectoral health team acknowledge the community as an active equal partner of the team, in a spirit of cooperation and acceptance will the goal of optimal health for all become more than an unattainable dream.

The development of self-management capabilities of local communities should be taken as essential, and finally the socioeconomic situations in the country should be conducive to development. Some of these conditions are very difficult for most developing countries to meet, yet it is in these developing countries that community participation could have the greatest impact affecting the people's health status.

Community participation has several advantages (WHO 1991:15) including that community participation at high levels empowers communities, increases self-reliance, self-awareness and self-confidence in self-examination of problems and in seeking solutions for them. Community participation promotes equity through sharing responsibility, solidarity and serving those in greatest need. Behavioural changes are promoted and utilisation and support of services are facilitated. Culturally more appropriate services are created as communities contribute their unique knowledge. However, the concept of community participation is a complex one. Its complexity lies not only in its many definitions but also in the fact that it has to be 
acceptable to the community, the service providers and the government (WHO 1996:16).

\section{Factors impeding community participation}

Sprayberry (1993:251) suggests that with any new idea, successful change does not occur without considerable attention to anticipated as well as to unforeseen problems, obstacles and opposition. Although there are several sound arguments for community participation, there are many factors which could impact negatively on sustainable community participation. Community participation is a very slow, time consuming process (Tumwine 1989:159; Shishana \& Versfield 1993: 8). General apathy of the community, lack of organisation, lack of leadership, and above all poverty can militate against community participation. Community participation should be a step by step process since it entails change in many aspects of peoples' lives, most importantly changing some of their values. Programmes to educate and train the communities might actually be hampered by a lack of financial and other important resources. Community participation will not be successful if the community itself is not prepared to partner with the health professionals and other community development agents. It becomes important to discover not only the views of the health professionals but also the community's expectations and views with regard to community participation. Community resources also need to be evaluated realistically. In many rural areas of Africa, women might be tending to young children and elderly people as well as people suffering from AIDS whilst attempting to work their fields to produce food for their families. These women might simply not have the time nor the energy to invest into any community health care programme.

Freyens, Mbakuliyemo and Martin (1993:253) refer to health professionals as intermediaries between the policy makers and the communities and emphasise that health professionals can therefore block or pass on instructions or suggestions. However, the health workers' understanding of community participation remains as important as that of the community. Courtney, Ballard, Fauver, Gariota and Holland (1996:180) emphasise that the community has to agree to form a partnership. For example, if health workers established the expectations of mothers regarding their participative role in ante-natal care, then the mothers and the health care workers should start collaborating to meet these expectations, and to establish mutual partnerships to meet the community's identified health care needs.

\section{Models of community participation}

Approaches to community participation differ from country to country, usually reflecting the socio-economic and political realities of each country (WHO 1995:225). Most developing countries have adopted the PHC approach to health development. Emphasis in these countries has been on involving the communities through two major approaches, namely the small scale community-based PHC projects and the large scale model which involves structural changes. In most developed coun- tries community participation is in the form of sharing information with individuals and in the developing countries community participation usually involves establishment of committees at local level and the participation of community representatives (WHO 1995:225). Participation in these two approaches differs in terms of groups involved. Models from both developed and developing countries will be discussed in order to derive recommendations for implementing community participation in health care programmes in developing countries.

\section{United States of America}

In the United States of America (USA) models such as Healthy Cities, Healthy Communities and Model for Standards Initiatives have been implemented. Health departments have worked together with communities in problem-solving actions, assessment of community health needs using science-based data, setting of priorities, implementation as well as evaluation and monitoring of health programmes (WHO 1995:225).

\section{United Kingdom}

The United Kingdom (UK) models seem to focus on individuals' participation in health promotion activities. However the public health movement in response to the WHO's call on Health for all by year 2000 seems to be moving towards the implementation of community participation at community level (WHO 1995:226).

\section{Canada}

The Canadian experience presents problems such as the selection of representatives to the boards strengthening the health management teams. The approach also failed to recognise the need to empower the selected members of boards and also the communities as such. The Canadian top down approach failed to bring about partnerships between the health care workers and the communities (NPPHCN 1999).

\section{Cuba}

The Cuban approach which followed a modified approach to the democratisation of health structures' power,creating powerpeople assemblies at each level of governance, achieved more successes than the Canadian approach (NPPHCN 1999). Two more strategies were used in Cuba namely the advisory committees, and the family doctor programme comprising health oriented personnel. In comparison to Canada, Cuba did not simply place people on governance structures but created space for the communities (NPPHCN 1999).

\section{Indonesia}

The Indonesian approach is an example where the communities became equal partners with the health services (Rohde, Chatterjee \& Moreley 1997:28; NPPHCN 1999). The community is involved in every phase of the programme, from the detection of a problem which is facilitated by a simple self- 
survey tool, to prioritisation and solution finding (Rohde, Chatterjee \& Morley 1997:31).

\section{Kenya}

An example of the small scale community-based PHC projects is found in Kenya where communities are involved in these projects and participate in the assessment of their own needs (NPPHCN 1999).

\section{Rwanda}

Freyens et al. (1993:253) conducted a survey in Rwanda on the health workers' perceptions of community participation. This study revealed reluctance of health workers to consider the promotion of situations in which they would not hold the initiative and authority, underestimating the people's potential and insistong on the need for hierarchical structures. Thus in this case health workers played a blocking role to community participation, and therefore recommendations were that health workers should be educated about community participation.

\section{Zimbabwe}

The small scale approach of many developing countries focuses on community health workers involved in the service provision, raising their awareness of health issues. This approach was adopted by Zimbabwe soon after independence in 1980, adopting committees similar to those operating in Cuba. This system was revised in 1995 when voluntary community workers (VCWs) were chosen. These VCWs were meant to be multipurpose persons executing health care activities, mobilising communities for income generating programmes and facilitating intersectoral collaborations.

Since 1995, the large scale model is applied in Zimbabwe where the health care system is organised at primary, secondary and tertiary levels. At each level there are committees including community representatives. There are limitations in both these two approaches. The community-based PHC projects, usually funded by non-governmental organisations (NGOs), might be difficult to duplicate in other areas due to a lack of financial resources. A realistic limitation is that the health programme can only last as long as the funding lasts unless the community, in collaboration with the health care workers, can find ways of sustaining the funding for specific programmes. The representative approach also has limitations including the election of the representatives, education and training of the representatives in order that they become equal partners and represent their communities effectively (WHO 1995:226). A challenge to the sustainability of the programme arises whenever a representative relocates to another part of the country, or even to another country, if and when job opportunities arise.

Both strategies were very promising at the beginning but several socio-economic factors caused slow progress in implementing and promoting the ideal of community participation. The Ministry of Health. Zimbabwe (1986:65) proposed the reintroduction of the village health workers suggesting that the VCWs might have been ineffective in coordinating the different activities from the various departments. There is an- other strategy which is in the process of implementation, the decentralisation process of health governance structures. This decentralisation process hopes to enhance community participation.

\section{Republic of South Africa (RSA)}

The large scale efforts have been implemented both in developing countries and developed countries. There is democratisation of health governance structures. The NPPHCN (1999) reported on community participation in the RSA.

In the RSA, the Mpumalanga and Western Cape Provinces took the implementation of community participation seriously. They assessed their socio-economic and political realities and then reviewed the different forms that had been implemented worldwide selecting those mechanisms that best suited their local conditions. Despite all these careful analyses of the situations, several problems were encountered in meeting the preconditions to community participation. Political differences, existing in the Western Cape Province, affected the strategies of informing the communities about the district development processes (NPPHCN 1999). This shows that community participation is a complex and dynamic process needing constant evaluation as well as adequate resources (including political commitment) for successful implementation.

\section{Evaluation of community participation in health care}

The international experiences show that preconditions have to be met for this approach to be sustainable (Shishana \& Versfeld 1993:7; Dennill et al. 1995:68; WHO 1995:225; NPPHCN 1999). It is, however, important to note the nature of these programmes, as many might not be due to the communities' initiatives. Outsider initiated programmes have a high risk for non sustainability, probably because of lack of commitment on the part of the communities concerned.

The tool that was designed by Rifkin et al. (1988:933) measures the extent of community participation only, the impact of community participation cannot easily be separated from those of other factors affecting the health outcomes of a community. Although it is difficult to measure the impact of community participation separately, several desirable effects are recognised. Shishana and Versfeld (1993:7) give five desirable effects of community participation:

- $\quad$ individual behavioral changes are promoted when the individual cooperates and is fully involved

- informal communication would allow effective dissemination and receiving of first hand information from the community and thus improved cover age of the poor

- $\quad$ communities share the burden of providing health care by providing material and human resources

- $\quad$ equity may be promoted through serving those with the greatest needs identified by the communities themselves

- where communities are involved in decision-making, members gain a sense of control over their lives. 


\section{Tools for assessing community participation}

Evaluation of the community participation strategies is very important, but it seems to be lacking in many countries implementing such initiatives. Rifkin et al. (1988:931) came up with five levels of participation following an analysis of 100 case studies on community participation in health programmes as summarised in Table 1.

Recommendations for
implementing health care
programmes with sustained
community participation in
developing countries

Recommendations for

implementing health care programmes with sustained developing countries

Table 1: Ranking scale for five process indicators for community participation

\begin{tabular}{|c|c|c|c|c|c|}
\hline & \multicolumn{5}{|l|}{ Ranks } \\
\hline & Narrow, nothing 1 & Restricted, small 2 & Mean, fail 3 & Open, much good 4 & $\begin{array}{l}\text { Wide, very much } \\
\text { excellent } 5\end{array}$ \\
\hline $\begin{array}{l}\text { 1. Leadership (L) } \\
\text { [Wealth minority-variety } \\
\text { of interests] }\end{array}$ & $\begin{array}{l}\text { One-sided (i.e. wealthy minority; } \\
\text { imposing ward-chaiman: health } \\
\text { staff assumes leadership; or: } \\
\text { inexistence of heterogeneous WHC }\end{array}$ & $\begin{array}{l}\text { WHC functioning under } \\
\text { the leadership of an } \\
\text { independent } \mathrm{CHL}\end{array}$ & $\begin{array}{l}\text { WHC functioning } \\
\text { under the leadership } \\
\text { of an independent } \\
\text { CHL }\end{array}$ & $\begin{array}{l}\text { Active WHC, taking } \\
\text { initiative }\end{array}$ & $\begin{array}{l}\text { WHC fully represents } \\
\text { variety of interests in } \\
\text { community and controls } \\
\text { CHL activities }\end{array}$ \\
\hline $\begin{array}{l}\text { 2. Organisation }(0) \\
\text { [Created by planners- } \\
\text { community } \\
\text { organization] }\end{array}$ & $\begin{array}{l}\text { WHC imposed by health services } \\
\text { and inactive }\end{array}$ & $\begin{array}{l}\text { WHC imposed by health } \\
\text { services, but developed } \\
\text { some activities }\end{array}$ & $\begin{array}{l}\text { WHC imposed by } \\
\text { health services, but } \\
\text { became fully active }\end{array}$ & $\begin{array}{l}\text { WHC actively } \\
\text { cooperating with other } \\
\text { community } \\
\text { organisations }\end{array}$ & $\begin{array}{l}\text { Existing community } \\
\text { organisations have been } \\
\text { involved in creating } \\
\text { WHC. }\end{array}$ \\
\hline $\begin{array}{l}\text { 3. Resources } \\
\text { Mobilisation (R.M) } \\
\text { [small commitment + } \\
\text { limited control-good } \\
\text { commitment + } \\
\text { committed control] }\end{array}$ & $\begin{array}{l}\text { Small amount of resources raised } \\
\text { by community. No fees for } \\
\text { services. WHC does not decide on } \\
\text { any resource allocation }\end{array}$ & $\begin{array}{l}\text { Fees for services. WHC } \\
\text { has no control over } \\
\text { utilisation of money } \\
\text { collected }\end{array}$ & $\begin{array}{l}\text { Community fund } \\
\text { raising periodically, } \\
\text { but no involvement in } \\
\text { control of expenditure }\end{array}$ & $\begin{array}{l}\text { Community fund } \\
\text { raising periodically and } \\
\text { WHC controls } \\
\text { utilisation of funds }\end{array}$ & $\begin{array}{l}\text { Considerable amount of } \\
\text { resources raised by fees } \\
\text { or otherwise. WHC } \\
\text { allocates the money } \\
\text { collected. }\end{array}$ \\
\hline $\begin{array}{l}\text { 4. Management }(\mathrm{M}) \\
\text { [professional induced- } \\
\text { community interests] }\end{array}$ & $\begin{array}{l}\text { Induced by health services. CHL } \\
\text { only supervised by health staff }\end{array}$ & $\begin{array}{l}\text { CHL manages } \\
\text { independently with some } \\
\text { involvement of WHC. } \\
\text { Supervision only by } \\
\text { health staff }\end{array}$ & $\begin{array}{l}\text { WHC self-managed } \\
\text { without control of } \\
\mathrm{CHL}=\mathrm{s} \text { activities }\end{array}$ & $\begin{array}{l}\text { WHC self-managed } \\
\text { and involved in } \\
\text { supervision of CHL }\end{array}$ & $\begin{array}{l}\text { CHL responsible to } \\
\text { WHC and actively } \\
\text { supervised by WHC. }\end{array}$ \\
\hline $\begin{array}{l}\text { 5. Needs Assessment } \\
\text { (NA) [professional view- } \\
\text { community involved] }\end{array}$ & $\begin{array}{l}\text { Imposed from outside with } \\
\text { medical, professional point of view } \\
\text { (CHL, VHW, HP-staff); or latrine } \\
\text { building programme imposed on } \\
\text { community }\end{array}$ & $\begin{array}{l}\text { Medical point of view } \\
\text { dominates an >educatio- } \\
\text { nal= approach. } \\
\text { Community interests are } \\
\text { also considered }\end{array}$ & $\begin{array}{l}\text { CHL is active } \\
\text { representative of } \\
\text { community view and } \\
\text { assessed the needs. }\end{array}$ & $\begin{array}{l}\text { WHC is actively } \\
\text { representing } \\
\text { community views and } \\
\text { assesses the needs. }\end{array}$ & $\begin{array}{l}\text { Community members in } \\
\text { general are involved in } \\
\text { needs assessment. }\end{array}$ \\
\hline
\end{tabular}

(Rifkin et al. 1988:931)

Adapted from Social Science Medicine 26(9):936

VHW B Village Health Worker; WHC $=$ Ward Health Committee; $\mathrm{CHL}=$ Community Health Leader; $\mathrm{HP}=\mathrm{Health}$ Post 
Health care workers should recognise communities to be entities which meet at least three criteria, namely that each community exists within a spatial, structural or common locality, that the members have interpersonal networks and provide social support functions to each other and to the community. Community participation, implying the interaction and co-operation of health care workers with community members, to implement, maintain and sustain health care programmes appropriate to the health care priorities of the community concerned, is the cornerstone of successful PHC services.

Community participation implies that the community members should be involved in identifying and prioritising health care needs as well as strategies for meeting these needs, and that each community should be empowered to make decisions about its own health care issues. This implies that health care workers should not impose their perceived priorities of specific communities' health care needs onto communities, even if these might be based on statistics or on survey results. (Communities might interpret disease prevalence in different cultural terms than the health care workers). Therefore health professionals should identify a community's strengths, opinion leaders and support networks in order to understand a specific community's health care priorities in terms of the community's perceptions. Health professionals should steer clear of both extremes of the continuum of community participation where these professionals render no inputs whatsoever or where they make all decisions without incorporating the community's contributions. Health professionals should render inputs based on their knowledge and experience concerning the management of disease patterns and the accessibility of human and material resources required to meet health care needs. However, political commitment of the country concerned is essential to the success of any community project. Health care professionals can also assist the community in obtaining commitment (and funds) from local, regional and national health care agencies to address their health care priorities. If the community's priorities include any issue addressed by an international agency or NGO, then health professionals could assist the community in obtaining funds from such international organisations, provided the national health authorities agree that these funds be sought and that the requirements attached thereto will be honoured at national and local levels.

Health professionals should encourage community participation at the individual, group as well as community levels. All three levels are required for sustained community participation striving to realise the ideals of self-care, demedicalisation and democratisation of health services. Community participation will be enhanced if there is political commitment and participation from the country's government, if the health care professionals have been trained for and are committed to enhancing community participation, and if the socio-economic situation is conducive to development of communities. Development of any community requirs multidisciplinary and intersectoral collaboration between health and all other agencies involved with commmunity development. Community participation remains a complex issue because it can only be sustainable if it is acceptable to the community concerned, the health care professionals and the government of the country. In cases where
NGOs offer sponsorship of programmes, their specifications also need to be met. The complexity of community participation increases with the number of stakeholders involved in each community project.

Externally imposed and foreign funded community programmes usually last no longer than the funds and manpower supplied from external and foreign sources because the local community never took ownership of these programmes.

Small scale community based PHC projects as well as large scale (often national) programmes have been employed in a number of developing and developed countries. Both approaches require that the communities concerned assume ownership of the specific programme(s) in order to ensure its sustainability. Time, effort and money invested in obtaining community participation prior to the implementation of any health programme will enhance the sustainability of any programme.

\section{Conclusion}

Community participation involves a partnership between the health care providers and the community, emphasising the importance of both parties to forming partnerships (Courtney et al. 1996:180). Health care professionals need to share power and form high level partnerships with communities in order to enhance the sustainability of community participation in health care programmes.

Small scale and large scale models of community participation in community health services have been implemented in different countries. Evaluation has mainly centered on the health care workers and the different types of programmes, but rarely on the actual involvement of the communities concerned. Studies also indicate that health care professionals have mainly focused on low level community participation such as individual self-care, rather than on group or community participation as such. A review of international experiences of community participation indicate that preconditions (government commitment and involvement, health care providers' training and commitment as well as some level of community development) need to be met for ensuring the success of sustainable community participation in health care programmes.

Enhancing the health and well-being of communities in developing countries requires wisdom, knowledge, commitment and political know-how in addition to finances. The world of ideas and the world of action are not separate ... but inseparable parts of each other. Ideas in particular, are truly pointed forces that shape the tangible world. The man and the woman of action have no less responsibility to know and understand than does the scholar ... (Donabedian in Harpham \& Tanner 1995:17).

\section{References}

APPS, JW 1994: Leadership for the emerging age: transforming practice in adult and continuing education. San Fransisco: Jossey-Bass. 
ASKEW, I: CARBALLO,J; RIFKIN,S \& SAUNDERS, D 1989: Policy aspects of community participation in maternal and child health and family planning programmes. Geneva: WHO.

BROWN, 1 1994: Community participation for general practice: perceptions of general practitioners and community nurses. Social Science \& Medicine. 39(3):335-344.

COURTNEY, R; BALLARD,E; FAUVER, S; GARIOTA, M \& HOLLAND, L 1996: The partnership model: working with individuals, families and communities towards a new vision of health. Public Health Nursing. 13(30):177-186.

\section{DENNILL, K; KING,L; LOCK,M \& SWANEPOEL, T 1995:} Aspects of primary health care. Durban: Southern.

FARLEY, $S$ 1993. The community as partner in primary health care. Nursing and Health Care. 14:244-249.

FREYENS,P; MBAKTЛIYEMO,N \& MARTIN,M 1993: How do health workers see community participation? World Health Forum. 14:253-257.

HARPHAM, T \& TANNER, M 1995: Urban health in developing countries: progress and prospects. London: Earthscan Publications.

KING, L 1996: Community participation in health care delivery; a nursing care perspective. Pretoria: University of South Africa. (D Litt et Phil thesis).

MINISTRY OF HEALTH AND WELFARE 1999: National health strategy for Zimbabwe 1997-2007: working for quality and equity in health. Harare: Screen Litho.

MINISTRY OF HEALTH, ZIMBABWE 1986: Zimbabwe health for all action plan. Harare: Government Printers.

MURRAY, SA 1996: Outreach programme in Kenya was based on extensive community participation. British Medical Journal, 312:250.

NATIONAL PROGRESSIVE PRIMARY HEALTH CARE NETWORK 1999: http:/www.health link:org.za/pphc/ idasal.htm.

NPPHCN see National Progressive Primary Health Care Network.

RIFKIN, SB 1990: Community participation in maternal and child health/family planning programmes: an analysis based on case study materials. Geneva: WHO/UNICEF.

RIFKIN, SB; MULLER, F \& BICHMANN, W 1988: Primary health care on measuring participation. Social Science \& Medicine 26: 931-940.

ROHDE, J; CHATTERJEE, M \& MORLEY,D 1997: Reaching health for all. Delphi: Oxford University Press.

SAWYER, LM 1995: Community participation: lip service? Nursing Outlook. 43:17-22
SHISHANA, O \& VERSFELD, P 1993: Community participation in health service institutions: South African Medical Journal, 83:5-8.

SPRAYBERRY, LD 1993: Nursing's dual role in health care policy. Nursing and Health Care. 14:250-251.

STANHOPE, M \& LANCASTER,J 1992: Community health nursing promoting health of aggregates families and individuals. St Louis: CV Mosby.

STANHOPE, M \& LANCASTER, J 1996: Community health nursing promoting health of aggregates families and individuals. St Louis: CV Mosby.

TUMWINE, JK 1989: Community participation as myth or reality: a personal experience from Zimbabwe. Community and public health nursing. 4 (2):157- 161.

WHO see World Health Organization.

WORLD HEALTH ORGANIZATION 1974: Expert committee on community health nursing report of WHO expert committee. Technical Report Series 558. Geneva: WHO.

WORLD HEALTH ORGANIZATION 1991: Community involvement in health development: challenging health services. Technical Report Series 809. Geneva: WHO.

WORLD HEALTH ORGANIZATION 1995: Progress towards health for all: third monitoring report. World Health Statistics Quarterly. 48(3/4). Geneva: WHO.

WORLD HEALTH ORGANIZATION 1996: Integration of health care delivery WHO study group. Technical Report Series 861 . Geneva: WHO.

WILSON, TD; ROBB, D; FERRINHO, P DE LGM \& NTSWANISI, D 1991: Insight into community participation. South African Medical Journal. 80:372-373. 